To cite this article: Adaeze Ukamaka, Jude Iwuoha, Lucky Oghenetega Urhiewhu \& Sandra Chidera Nwachukwu (2020) Awareness of Career Prospects in Librarianship and Students Preparedness in Library Schools in South-East, Nigeria. Information Impact: Journal of Information and Knowledge Management, 11:4, 117-128, DOI: https://dx.doi.org/10.4314/iijikm.v11i4.11

To link to this article: https://dx.doi.org/10.4314/ijjikm.v11i4.11

\title{
Awareness of Career Prospects in Librarianship and Students' Preparedness in Library Schools in South-East Nigeria
}

\author{
${ }^{1}$ Adaeze Ukamaka \\ 1 Jude Iwuoha \\ ${ }^{2}$ Lucky Oghenetega Urhiewhu \\ ${ }^{3}$ Sandra Chidera Nwachukwu \\ ${ }^{1}$ Michael Okpara University of Agriculture Library, Umudike, Abia State, Nigeria \\ ${ }^{2}$ University of Medical Sciences, Ondo, Nigeria \\ ${ }^{3}$ Department of Library and Information Science, Michael Okpara University of Agriculture Umudike, Nigeria
}

\begin{abstract}
The paper focused on Awareness of Career Prospects in librarianship and students' preparedness in library schools, South- East Nigeria. Descriptive survey research design method was adopted in this study. A total population of 552 respondents covering only final year students of the Library and Information Science Department of library schools in South-East was used for this study, to which 112 were randomly selected. Data was collected by means of a questionnaire and handbook for undergraduate programmes from 2012 to 2019 in each university where Library and Information Science is offered. Findings showed that information networking, software package, and library automation are taught by ESUT, IMSU, NAU, and ABSU only. While literature searching skills is not taught by any of the universities understudied, Introduction to ICT \& Internet in Library and information services courses are taught by ESUT, IMSU and NAU. In addition, Electronic publishing and IT tools and computer application are taught only in MOUAU. It was also revealed that students are aware of the following information outlets: libraries, schools, archives, banks, media houses, museums, education and training institutions for information personnel, among others. Results indicated that SIWES and school coursework were the major events put in place in preparing students for a career in librarianship. Recommendations were made based on the findings.
\end{abstract}

Keywords Awareness, Career prospects, Librarianship, Library schools

CONTACT Adaeze Ukamaka, Jude Iwuoha, Lucky Oghenetega Urhiewhu and Sandra Chidera Nwachukwu adizy2003@yahoo.com Michael Okpara University of Agriculture, Umudike, Nigeria and Univrsity of Medical Sciences, Ondo, Nigeria. 2020 The Authors Published with License by Information Impact 


\section{Introduction}

Choosing a career path can help you set professional goals and develop a strategy for getting where you want to be. Choosing a career by the individual is one of the most important yet, difficult decisions to make in lifetime, since everyone deserves that right to make the choice. Career determines our lifestyle, activity, pastime and, of course, income. A child dreams of what to become in future but finds out that the goals to be attained in life change just as the preferred career becomes largely influenced by what is possible to be done. The individual looks forward to a fulfillment in a chosen career by its reward system, although the rewards are not always the same. Some are into career so as to be looked up to; others derive great satisfaction from a job well done. Career is seen as an unfolding sequence of an individual's work-related and other relevant experiences, both inside and outside organizations which forms a unique pattern over the individual's lifespan (Sullivan \& Baruch, 2009 cited in Mullhall, 2014).

The Bureau of Labor Statistics (2018) has it that an average person appends 8.8 hours per day at work - essentially showing that career people spend more time on the job in life. This means a career choice is very necessary. The right career can provide years of enjoyment, challenge and personal enrichment. Library and Information Science offers an incredible range of opportunities to 'make a living, making a difference'. When students are aware of the variety of career opportunities open to them as prospective information experts, they can make better career decisions. Thus, this brings to limelight, the thrust of this paper which is awareness of career prospects and preparedness of students in Library Schools in South-East, Nigeria.

Application, admission and retention of students in Library and Information Science undergraduate programme has been a critical issue in Nigeria. It has been observed that only a few under-graduates usually apply to study Library and Information Science as first choice course. Many who are eventually admitted into library schools enroll either because they were influenced or it was the only alternative left since they were unable to secure admission in other preferred departments.

This development tends to turn library schools in Nigeria into dumping grounds for candidates who could not be admitted to study their preferred courses. These students who resign to this fate, just flow with the passage of time not really having a distinct plan of what to do after school. Others begin to make arrangements for a second degree in their preferred course of study. This is because they see the work of a librarian as "books and boring" and they are not aware of other outlets where they can work outside the library - implying that little or no preparation is made to fit in the work environment of the librarianship career. The limited opportunities for employment of library and information science graduates, is also disheartening. This signals danger for the future of the Library and Information Science profession in Nigeria.

Most researchers point at the opportunities that abound in the library setting. They also stress being employed by somebody - job seeking and not job creation. Technical service librarians obtain, prepare, and organize library materials; administrative librarians are focused on the more businessoriented aspects of the library; corporate librarians are hired by private businesses; law librarians work in law libraries and so on (Stauf and Bread, 2016). All these are circled around the library. They can also work as information officers, knowledge officers, knowledge managers, communications and relationship officers, field officers and in Community Based Organizations (CBOs) and NonGovernmental Organizations (NGOs) (Kolawole and Igwe, 2016).

This explains that there is a gap in publicizing self-initiated Library and Information related careers. If not properly managed, this can discourage a lot of people from venturing into this career which is already poorly publicized in Nigeria. Hence, this study tends to ascertain the students' knowledge of the career opportunities that abound in librarianship and their preparedness for the 
career. The students in the library schools of South- East, Nigeria would be used as case study to measure the level of awareness.

\section{Research questions}

The following research questions have been raised:

- What are the career courses taught in different library schools in South-east?

- What are the available career opportunities known to Library and Information Science students?

- To what extent are the students aware of the career opportunities in librarianship as a profession?

- Are the students aware of the available information outlets a library and information professional can work?

- What events are designed in the curricular to prepare the students for the career?

\section{Literature review}

A career is known as an occupation, or a chosen profession which generates some income for an individual. It is an ultimate phenomenon that involves building and creating an identity that determines the relevance of a person in the society he belongs to (Yusuf \&Ilo 2012). A career is also said to be an occupation which is undertaken for a significant period of a person's life. Thus, career development is increasingly seen not as being chosen, but as being constructed, through the series of choices about learning and work that people make throughout their lives (Cullen, 2013). Career development therefore, can be defined as an organized approach used to match employee goals with the business needs of the agency in support of workforce development initiatives (Petricca, Harris \& McKenna, 2013).

Over the years, a number of studies have shown that career development has several implications for both employees and organisations. Wilson and Halpin (2006) stated that most successful organizations adjust their talent management strategies to focus on development, and to provide solutions that put their employees in control of their own careers. Tomaszewski and MacDonald (2009) also observed that, employee development is a prerequisite to employee productivity and sustenance of competitive advantage in the challenging business environment nowadays. Furthermore, Cooke (2012) pointed out that through innovation and employee career development process; an organization will benefit from improved performance, mobilize talent as needed, adjust to rapid changes in the environment and thereby retain their most critical talents. Many organizations therefore, have, realized that developing the talents and skills of their workforces in the global economy is the chief means of staying competitive. Consequently, employees' career developmental needs must be consciously linked with the organizations workforce needs as well as its strategic direction.

Librarianship in Nigeria has evolved over the years to the extent that the concept of the profession and the practitioners is changing for the better. The history of librarianship in Nigeria as discussed by Aguolu and Aguolu (2002) revealed a continual conflict between two opposing factors: those who want libraries and fought to have them established and those who resisted their establishment and expansion. Library and Information Science, library science, library studies and librarianship are concepts that are used interchangeably. At the inception of the multidisciplinary field, librarianship was used mostly, later followed by library studies, library science, and now library and information science. Aina (2013) noted that there is generally no distinction among the concepts just that they emerged in response to rapid social and technological developments. Thus, the profession has 
evolved from librarianship to library studies to library science, and to library and information science, which has led to the movement from physical libraries to digital and virtual libraries. The application and use of computers and other digital technologies for provision of information services to users is now a trend that needs not be neglected by service providers in libraries and information centers. The growth and importance of libraries brought about the profession of librarianship. Kolawole and Igwe (2016) posited that Library and Information Science is a profession that is full of people passionate about making a positive change in the world and they tend to be wildly happy about what they do. These people are librarians and other classes of information practitioners.

Librarianship is a profession that substantially deals with the human beings and their information needs, their information seeking behavior, their attitudes, their information environment, resources provision and utilization. It is classified as a behavioral science that seeks to understand and provide man with his information needs and its resources. It adopts all the social science methods of investigation in terms of research design, procedure, data collection techniques, data analysis and the use of social science testing and statistical tools (Uhegbu, 2009). Librarianship can be defined as a profession that is devoted to applying theory and technology to the creation, representation, selection, acquisition, organization, management, preservation, retrieval, dissemination and utilization of information of collections in all formats by users in the society. A person formally trained or certified to perform such services is a librarian (Reitz, 2002). Unlike other professions, it is not subject-specific.

An individual is adjudged a professional because he/she has knowledge and skills in a particular discipline and to which the "commoner" or the unprofessional seek this knowledge. Librarians are professionals due to their knowledge and ability to bring order to a world of "information chaos". They carry out various routine duties which those who are not trained in the same profession cannot undertake easily. Some of these routine duties as noted by Ugah (2014) include:

- Selection and acquisition of information resources to meet the information needs of any kind and class of user;

- Cataloguing and classification of information materials;

- Indexing and abstracting of information resources in any field of knowledge;

- Teaching a varied kind of library users on information literacy;

- Researching on topical issues in any field knowledge;

- Teaching, preparing and graduating of manpower in the library and information profession;

- Management of electronic versions of information resources;

- Digitization of teaching and learning resources; etc.

However, technological advancement has also given the profession a lift such that a librarian is no longer confined to the "four walls" of a library and neither has the place of the librarian been eroded by the Internet. Rather, this technological platform enhances a librarian's information role, such that the librarian of today doubles as a programmer, webmaster, digital curator, electronic librarian, Internet searcher, database manager, and so on (Igbinosa, 2007). There are a number of career opportunities available to qualified and versatile library and information science professional at all levels within and outside the traditional library profession. Some of these positions include librarian, archivist, records manager, information scientist, information broker, information systems analyst and designer, database manager, cataloguer, abstractor, indexer, classifier, curator, editor, educator, book publisher (Edoka, 1991; Aina, 2004 and Anyanwu, Amadi \& Oparaku, 2010). Trained library and information professionals can find opportunities for employment as teacher-librarians, lecturers and as librarians. It is possible to choose the kind of library one may like to make a career depending on one's interest and background. The explosion of technology has also widened the employment prospects of librarians; they are no longer limited to working in libraries only. As information experts, they work in 
all kinds of settings. Their skills in management, communication, organization, and systems design and information classification are in demand in fields such as archives, records management and systems analysis (Canadian Librarian Associations, CLA (2005). Increasingly graduates from library and information science programmes are choosing non-traditional paths. This new breed can be found working in publishing companies or companies that supply goods and services to libraries. Some become web masters, independent information consultants or start their own information-related business. They may hold management positions in associations or corporate positions like electronic image manager or risk management researcher. They can also work in banks, embassies and high commissions, business houses, data centres, media houses, international organizations, and so on (Ugah, 2014). The possibility of library and information science professionals working in different firms grow yearly, as emerging information technologies create a need for more information specialists.

For students to be successful in the afore-mentioned careers in librarianship, then certain grounds must be gained during their stay in the library school. Students' level of preparedness is largely dependent on the curriculum scope, practical, SIWES, excursions and personal efforts. The curriculum of any library and information science program should include core courses like cataloguing and classification, indexing and abstracting, library automation, reference services, infopreneurship, etc. These courses, which should have comprehensive course outlines, would equip the students to undertake a business in any of those fields or related fields after graduation. According to a study carried out on "new cataloguers' preparedness" by Dulock, (2011), fifty per cent of interviewees indicated they would have liked to have taken additional cataloguing courses, or more advanced cataloguing coursework, in order to be better prepared for their positions. They result of the study also revealed that students who did not participate in a cataloguing practicum felt less prepared for their professional cataloguing positions than students who did. Therefore significant hands-on experience in addition to a theoretical background is needed in preparation of LIS students for a career in librarianship. Students interested in pursuing professional development opportunities in librarianship also need to attend conferences, join local and national library organizations, attend parttime work or an internship in a library or allied centres, or seek out an independent study in the field.

\section{Methodology}

The study employed descriptive survey using undergraduate students in 7 public university Library Schools in South- East Nigeria, namely - Abia State University, Uturu (ABSU), Chukwuemeka Odumegwu Ojukwu University (COOU), Enugu State University of Technology (ESUT), Imo State University (IMSU), Nnamdi Azikiwe University (NAU), Michael Okpara University of Agriculture Umudike (MOUAU) and University of Nigeria Nsukka. A sample size of 112 students was randomly selected from a total population of 552 final year students in the 2018/2019 academic session. The focus is on final year students only because they are already in their terminal class and it is believed they have passed through the recommended coursework and are in a better position to objectively complete the questionnaire. A questionnaire titled "Awareness of Career Prospects in Librarianship and Students' Preparedness in Library and Information Science (ACPLSPLS)" was used to gather data from students in the library schools. Respondents were asked to specify their level of agreement on a four-point likert scale. In addition, the handbook for undergraduate programme from each of the Library Schools understudy was also used to collect data on the recommended coursework. Data collected were analyzed using frequency counts, and mean scores. 


\section{Results and Discussion}

The results of this study was analyzed using reporting system, frequency counts, and mean scores and presented in the tables below to discover the students' awareness of the career opportunities associated with librarianship and their preparedness for the opportunities.

Research Question One: What are the career courses taught in different library schools in South-East?

Table 1: Career Courses Taught in Library Schools in South-East, Nigeria.

\begin{tabular}{|c|c|c|c|c|c|c|c|}
\hline \begin{tabular}{l}
\multicolumn{2}{l}{ Career Courses } \\
offered in \\
Library \\
Schools
\end{tabular} & $\begin{array}{l}\text { Michael } \\
\text { Okpara } \\
\text { University of } \\
\text { Agriculture, } \\
\text { Umudike } \\
\text { (MOUAU) }\end{array}$ & $\begin{array}{l}\text { Enugu State } \\
\text { University of } \\
\text { Science and } \\
\text { Technology, } \\
\text { Agbani(ESUT } \\
\text { ) }\end{array}$ & $\begin{array}{l}\text { Imo State } \\
\text { University, } \\
\text { Owerri } \\
\text { (IMSU) }\end{array}$ & $\begin{array}{l}\text { NnamdiAziki } \\
\text { we } \\
\text { University, } \\
\text { Awka(NAU) }\end{array}$ & $\begin{array}{l}\text { University of } \\
\text { Nigeria } \\
\text { Nsukka(UNN) }\end{array}$ & $\begin{array}{l}\text { Abia State } \\
\text { University, } \\
\text { Uturu(ABSU) }\end{array}$ & $\begin{array}{l}\text { Chukwuemka } \\
\text { OdumegwuOj } \\
\text { ukwu } \\
\text { University, } \\
\text { Igbariam(CO } \\
\text { OU) }\end{array}$ \\
\hline $\begin{array}{l}\text { Introduction to } \\
\text { computer and } \\
\text { communication } \\
\text { skills }\end{array}$ & $\sqrt{ }$ & - & $\sqrt{ }$ & $\sqrt{ }$ & - & - & $\sqrt{ }$ \\
\hline $\begin{array}{l}\text { IT tools and } \\
\text { computer } \\
\text { application } \\
\end{array}$ & $\sqrt{ }$ & - & - & - & - & - & - \\
\hline $\begin{array}{l}\text { Introduction to } \\
\text { Entrepreneurshi } \\
\mathrm{p}\end{array}$ & $\sqrt{ }$ & $\sqrt{ }$ & $\sqrt{ }$ & $\sqrt{ }$ & $\sqrt{ }$ & $\sqrt{ }$ & $\sqrt{ }$ \\
\hline $\begin{array}{l}\text { Electronic } \\
\text { publishing }\end{array}$ & $\sqrt{ }$ & - & - & - & - & - & - \\
\hline $\begin{array}{l}\text { Communication } \\
\text { and marketing of } \\
\text { information } \\
\text { services }\end{array}$ & $\sqrt{ }$ & $\sqrt{ }$ & $\sqrt{ }$ & $\sqrt{ }$ & $\sqrt{ }$ & $\sqrt{ }$ & $\sqrt{ }$ \\
\hline $\begin{array}{l}\text { Technical } \\
\text { processes and } \\
\text { service }\end{array}$ & $\sqrt{ }$ & $\sqrt{ }$ & $\sqrt{ }$ & $\sqrt{ }$ & $\sqrt{ }$ & $\sqrt{ }$ & $\sqrt{ }$ \\
\hline $\begin{array}{l}\text { Indexing and } \\
\text { Abstracting }\end{array}$ & $\sqrt{ }$ & $\sqrt{ }$ & $\sqrt{ }$ & $\sqrt{ }$ & $\sqrt{ }$ & $\sqrt{ }$ & $\sqrt{ }$ \\
\hline $\begin{array}{l}\text { Websites } \\
\text { development } \\
\text { and internet } \\
\text { technology }\end{array}$ & $\sqrt{ }$ & $\sqrt{ }$ & $\sqrt{ }$ & $\sqrt{ }$ & $\sqrt{ }$ & $\sqrt{ }$ & - \\
\hline $\begin{array}{l}\text { Principles of } \\
\text { public relations }\end{array}$ & $\sqrt{ }$ & - & $\sqrt{ }$ & - & - & $\sqrt{ }$ & $\sqrt{ }$ \\
\hline $\begin{array}{l}\text { Book trade and } \\
\text { publishing }\end{array}$ & $\sqrt{ }$ & $\sqrt{ }$ & $\sqrt{ }$ & $\sqrt{ }$ & $\sqrt{ }$ & $\sqrt{ }$ & $\sqrt{ }$ \\
\hline Infopreneurship & $\sqrt{ }$ & $\sqrt{ }$ & $\sqrt{ }$ & $\sqrt{ }$ & $\sqrt{ }$ & $\sqrt{ }$ & $\sqrt{ }$ \\
\hline $\begin{array}{l}\text { Introduction to } \\
\text { ICT \& Internet in } \\
\text { Library and } \\
\text { information } \\
\text { services }\end{array}$ & $\sqrt{ }$ & - & - & - & $-\sqrt{ }$ & $\sqrt{ }$ & $\sqrt{ }$ \\
\hline $\begin{array}{l}\text { Software } \\
\text { packages }\end{array}$ & - & $\sqrt{ }$ & - & - & - & - & - \\
\hline $\begin{array}{l}\text { Information } \\
\text { networking }\end{array}$ & - & $\sqrt{ }$ & - & - & - & - & - \\
\hline $\begin{array}{l}\text { Literature } \\
\text { Searching Skills }\end{array}$ & - & - & - & - & - & - & - \\
\hline $\begin{array}{l}\text { Library } \\
\text { Automation }\end{array}$ & - & - & $\sqrt{ }$ & - & $\sqrt{ }$ & $\sqrt{ }$ & - \\
\hline
\end{tabular}


Table 1 above shows the courses taught in different library schools in South-East of Nigeria. It was observed that, information networking, software package, and library automation were taught by ESUT, IMSU, NAU, and ABSU, respectively. While literature searching skills was not taught by any of the library schools understudy, Introduction to ICT \& Internet in Library and information services course are taught by ESUT, IMSU and NAU. Another findings showed that Electronic publishing and IT tools and computer application were taught only in MOUAU library school.

The only courses that are similar in all the library schools includes- book trade and publishing, introduction to entrepreneurship, infopreneurship, communication and marketing of information services, technical processes and service and indexing and abstracting. Findings also showed that different department interchange name of courses and many of the courses were taught theoretically without practical. This is the cause of students not being prepared for career opportunities in librarianship.

Research Question One: What are the available career opportunities known to Library and Information Science students?

Table 2: Available Career Opportunities

\begin{tabular}{|c|c|c|c|c|c|c|c|}
\hline $\mathbf{S} / \mathbf{N}$ & $\begin{array}{l}\text { CAREER } \\
\text { OPPORTUNITIES }\end{array}$ & SA & A & D & SD & Mean & Dec. \\
\hline 1 & $\begin{array}{lcr}\text { Librarian in } & \text { academic, } \\
\text { school and } & \text { research } \\
\text { libraries } & & \end{array}$ & 97 & 13 & 0 & 0 & 3.88 & A \\
\hline 2 & $\begin{array}{l}\text { Librarian/information officer } \\
\text { in radio, television, } \\
\text { newspaper and magazine } \\
\text { houses }\end{array}$ & 73 & 22 & 15 & 0 & 3.53 & A \\
\hline 3 & Editor & 59 & 20 & 31 & 0 & 3.25 & A \\
\hline 4 & Business consultant & 11 & 42 & 37 & 20 & 2.40 & $\mathrm{R}$ \\
\hline 5 & Information Broker & 66 & 34 & 8 & 2 & 3.49 & A \\
\hline 6 & Library educator & 52 & 46 & 12 & 0 & 3.36 & $A$ \\
\hline 7 & Public relations officer & 0 & 37 & 67 & 6 & 2.28 & $\mathrm{R}$ \\
\hline 8 & Records manager & 21 & 89 & 0 & 0 & 3.19 & $A$ \\
\hline 9 & Database manager & 9 & 43 & 22 & 36 & 2.23 & $\mathrm{R}$ \\
\hline 10 & Curator & 0 & 21 & 75 & 14 & 2.06 & $\mathrm{R}$ \\
\hline 11 & Lecturer & 110 & 0 & 0 & 0 & 4 & A \\
\hline 12 & Abstractor & 78 & 32 & 0 & 0 & 3.71 & $A$ \\
\hline 13 & Indexer & 98 & 9 & 3 & 0 & 3.71 & A \\
\hline 14 & Book publisher & 92 & 18 & 0 & 0 & 3.84 & A \\
\hline 15 & Archivist & 90 & 13 & 7 & 0 & 3.75 & $A$ \\
\hline 16 & Inforpreneur & 77 & 20 & 13 & 0 & 3.58 & $A$ \\
\hline
\end{tabular}


The most known career opportunities in librarianship as a profession are; lecturer, which accounted for (4) as the mean score, librarian in academic, school and research libraries (3.88), book publisher (3.84), archivist (3.75), indexer (3.71) and abstractor (3.71). Inforpreneur (3.58), librarian/information officer in media houses (3.52), information broker (3.49), library educator (3.36), editor (3.25) and records manager (3.19), were also familiar to the students. Business consultant, database manager, public relations officer and curator are not yet known to the respondents. The reason for the negative result in these four is not farfetched. It can be attributed to availability of information on available career prospects collaborating the findings of Issa and Nweke (2008) who found that the course Library and Information Science remains mostly unpopular among prospective students when compared with other courses such as accountancy, economics etc.

Research Question Two: To what extent are the students aware of the career opportunities in librarianship as a profession?

Table 3: Extent of Students' Awareness of Career Opportunities.

\begin{tabular}{|c|c|c|c|c|c|c|c|}
\hline $\mathbf{S} / \mathbf{N}$ & ITEM & VGE & GE & LE & NE & Mean & Dec \\
\hline 1 & $\begin{array}{l}\text { Librarian in academic and research } \\
\text { libraries }\end{array}$ & 107 & 3 & 0 & 0 & 3.97 & $A$ \\
\hline 2 & $\begin{array}{l}\text { Librarian/information officer in radio, } \\
\text { television, newspaper and magazine } \\
\text { houses }\end{array}$ & 105 & 5 & 0 & 0 & 3.95 & $A$ \\
\hline 3 & Editor & 32 & 46 & 20 & 12 & 2.89 & $A$ \\
\hline 4 & Business consultant & 15 & 24 & 41 & 30 & 2.22 & $\mathrm{R}$ \\
\hline 5 & Information Broker & 62 & 33 & 15 & 0 & 3.43 & A \\
\hline 6 & Library educator & 76 & 34 & 0 & 0 & 3.69 & A \\
\hline 7 & Public relations officer & 0 & 37 & 66 & 7 & 2.27 & $\mathrm{R}$ \\
\hline 8 & Records manager & 23 & 74 & 13 & 0 & 3.09 & A \\
\hline 9 & Database manager & 13 & 23 & 46 & 29 & 2.20 & $\mathrm{R}$ \\
\hline 10 & Curator & 0 & 23 & 73 & 14 & 2.08 & $\mathrm{R}$ \\
\hline 11 & Lecturer & 110 & 0 & 0 & 0 & 4 & A \\
\hline 12 & Abstractor & 70 & 40 & 0 & 0 & 3.64 & $A$ \\
\hline 13 & Indexer & 74 & 32 & 4 & 0 & 3.64 & $A$ \\
\hline 14 & Book publisher & 12 & 97 & 1 & 0 & 3.10 & $A$ \\
\hline 15 & Archivist & 87 & 16 & 7 & 0 & 3.73 & A \\
\hline 16 & Inforpreneur & 91 & 19 & 0 & 0 & 3.83 & $A$ \\
\hline
\end{tabular}


The study also sought to determine the extent of students' awareness of career opportunities in library and information profession. Their responses are captured in Table 3 above. Top on the list of career opportunities known to the respondents is lecturer with a criterion mean of 4 . This is followed by librarian in academic and research libraries and librarian/information officer in media houses with a mean score of 3.97 and 3.95, respectively. Again Public relation officer, business consultant, database manager and curator did not receive an acceptable response rate from the students, having mean scores below 2.5. This means that the students are yet to discover these grey but lucrative opportunities library and information science profession can fetch for them. This once again is attributed to limited information on the existence of career prospects in these areas, lending credence once more to the study by (Issa \& Nwalo, 2008). From the foregoing, it is evident that the career choice of an individual can be charted on the basis of the amount of information available to him about different kinds of career.

Research Question 3: Are the students aware of the available information outlets a library and information professional can work?

Table 4: Awareness of Available Information Outlets

\begin{tabular}{|c|c|c|c|c|c|c|c|}
\hline $\mathrm{S} / \mathrm{N}$ & INFORMATION OUTLETS & SA & $\mathbf{A}$ & D & SD & Mean & Dec. \\
\hline 1 & Schools & 98 & 12 & 0 & 0 & 3.89 & A \\
\hline 2 & Libraries & 110 & 0 & 0 & 0 & 4 & A \\
\hline 3 & Government offices & 89 & 21 & 0 & 0 & 3.81 & A \\
\hline 4 & Publishing Houses & 93 & 17 & 0 & 0 & 3.85 & A \\
\hline 5 & Banks & 101 & 9 & 0 & 0 & 3.92 & A \\
\hline 6 & $\begin{array}{l}\text { Media houses (radio, television, } \\
\text { newspaper) }\end{array}$ & 101 & 9 & 0 & 0 & 3.92 & A \\
\hline 7 & Database industries & 9 & 36 & 39 & 26 & 2.25 & $\mathrm{R}$ \\
\hline 8 & Archives & 105 & 5 & 0 & 0 & 3.95 & A \\
\hline 9 & Bookshops & 12 & 98 & 0 & 0 & 3.11 & A \\
\hline 10 & Communication outlets & 90 & 19 & 1 & 0 & 3.81 & A \\
\hline 11 & Museums & 101 & 9 & 0 & 0 & 3.92 & $A$ \\
\hline 12 & $\begin{array}{l}\text { Education and } \begin{array}{c}\text { training } \\
\text { institutions for information } \\
\text { personnel }\end{array} \\
\end{array}$ & 99 & 11 & 0 & 0 & 3.90 & A \\
\hline 13 & $\begin{array}{l}\text { Embassies and High } \\
\text { Commissions }\end{array}$ & 17 & 33 & 19 & 41 & 2.24 & $R$ \\
\hline 14 & International organizations & 98 & 8 & 4 & 0 & 3.85 & A \\
\hline 15 & Business houses & 19 & 34 & 44 & 13 & 2.54 & A \\
\hline 16 & Hospitals & 23 & 27 & 57 & 3 & 2.64 & $A$ \\
\hline 17 & Law firms & 12 & 41 & 50 & 7 & 2.53 & A \\
\hline
\end{tabular}

In Table 4 above, it was revealed that students are aware of the following information outlets: libraries, archives, banks, media houses, museums, education and training institutions for information personnel, schools, international organizations, publishing houses, government offices and communication outlets. Bookshops, hospitals, embassies and high commissions, business houses and law firms scored above the benchmark. Database industries and embassies and high commissions were not considered as a popular information outlet a library and information professional can work since they received 2.25 and 2.24 as mean score, respectively.

The negative response on awareness of database industries and embassies and high commissions as information outlets can be attributed to students' reason and career expectations while studying the course. Most students are found not to intentionally apply for this course but rather study 
it because either they were desperate to enter the university or that they did not make up to the score for admission in their preferred courses. This supports the findings of Allyson et al (2006) who advised all librarians to seek to learn more about students' career motivations and professional interests so that they can recruit more people to the profession and accommodate their needs.

Research Question 4:What events are laid out in the curricular to prepare the students for the career?

Table 5: Events Designed in the Curricular.

\begin{tabular}{|c|c|c|c|c|c|c|c|}
\hline $\mathbf{S} / \mathbf{N}$ & EVENTS & SA & $\mathbf{A}$ & D & SD & Mean & Dec. \\
\hline 1 & School coursework & 107 & 3 & 0 & 0 & 3.97 & $\mathrm{~A}$ \\
\hline 2 & Seminars & 67 & 38 & 5 & 0 & 3.56 & $A$ \\
\hline 3 & $\begin{array}{l}\text { Library } \\
\text { conferences/workshops }\end{array}$ & 13 & 20 & 43 & 34 & 2.11 & $\mathrm{R}$ \\
\hline 4 & Debates & 3 & 8 & 87 & 12 & 2.01 & $\mathrm{R}$ \\
\hline 5 & Practical & 73 & 20 & 1 & 16 & 3.36 & $A$ \\
\hline 6 & Excursions & 73 & 24 & 9 & 4 & 3.51 & A \\
\hline 7 & SIWES/Internship & 108 & 2 & 0 & 0 & 3.98 & $A$ \\
\hline
\end{tabular}

From Table 5, it is evident that school coursework and SIWES/internship were the major activities put in place in the curricular to get the students ready for a career in librarianship. This was supported by a mean score of (3.98) response rate from the students in each case. Seminar was another event carried out to prepare students for a career in librarianship as well as excursion, with mean scores of (3.56) and (3.51), and respectively. Though response rate with a mean score of 3.36 showed that practical is being laid out to prepare students for a career in the library profession, it is of concern that library conferences/workshops and debates have not attracted the interest of these library school as regards preparing their students for a career in librarianship.

\section{Conclusion and Recommendations}

Career in Library and Information Science remains mostly unpopular among prospective students when compared with other courses such as medicine, nursing, accountancy, engineering, and so on. The study revealed the different courses taught in the Library schools understudied. The nomenclatures used as the course title and code varied and were confusing in the Library schools understudied. Furthermore, from the findings above, it is obvious to note that most students studying Library and Information Science public universities in South-East Nigeria are only aware of career opportunities based on the fact that they have only come in contact or have heard of people in those fields of endeavour. This made them to be much aware of the existence of these career prospects in most areas. Apathy regarding the choice of this course of study contributes to the limited knowledge of career prospects in certain areas. However, sensitization on the abounding opportunities and career talks would have done better in this regard.

Based on the findings of this research, it is recommended that:

- Students should be made to freely discuss their intended dreams regarding career with various course advisers and counselors.

- Library and Information Science curricular should be redesigned to capture career talks, multidisciplinary tasking and management to encourage recruitment of students as well as to suit the current trend of career development in the $21^{\text {st }}$ century librarianship.

- Library schools should review their training objectives to cater for information - related jobs other than the training of librarians. 


\section{References}

Aguolu, C. C. (2002). Problems facing the library profession in Nigeria. In Aguolu, C. C.(ed)

Libraries and Information Management in Nigeria. Maiduguri, ED-Linform Services.

Aina, L. O. (2013). Information, knowledge and the gatekeeper. 132nd inaugural lecture presented on May 16th at the University of Ilorin, Ilorin, Nigeria.

Aina, L. O. (2004). Library and information science text for Africa. Ibadan: Third world Information Service. $369 \mathrm{p}$.

Allyson, A. et al (2006). Why Library and Information Science? The Results of a Career Survey of MLIS Students Along with Implications for Reference Librarians and Recruitment. Reference and User Services Quarterly 45(3):236-248. Retrieved from https://scholarworks.gsu.edu/cgi/viewcontent.cgi?article=1026\&context=univ_lib_facpub Anyanwu, E. U., Amadi, E. I. \&Oparaku, D. C. (2011). Introduction to entrepreneurship development. Owerri: Springfield Publishers.

Campbell, F., Marcella, R. \& Baxter, G. (2000). Professional development and the recently qualified information and library studies professional: factors affecting success in attainment of the UK library association associate's status, Education for Information, 18(2/3), 169-199.

Cooke, N. A. (2012). Professional development 2.0 for librarians: developing an online personal learning network (PLN), Library Hi Tech News, 29(3), 1 - 9.

Dulock, M. (2011). New cataloguer preparedness: interviews with new professionals in academic libraries. Cataloguing and classification quarterly 49 (2), 65-96. Retrieved from https://doi.org/10.1080/01639374.2011.538910

Edoka, B. E. (1991). Prospects of priced information services in public funded libraries in Nigeria. African journal of library and information science, 1 (2). 83-92.

Igbinosa, I. O. (2007). University of Benin students' perception of library and information science profession. Nigerian Library Link, 5 (1). 74-82.

Isaa, A. O. \&Nwalo, K.I.N. (2008). Factors affecting the career choice of undergraduates in Nigerian Library and Information Science Schools. African Journal of Library, Archives and Information science, 18 (1). 23-31.

Ismail, N. B. (2006). An exploratory study of upper secondary school students towards librarianship as a career. (Masters' Theses, Library and information Science, University of Maleya, Kuala, Lumpur). Retrieved from https:// repository. um. edu. my/226/1/An\%20exploratory\%20study\%20of\%20upper\%20secondary\%20school $\% 20$ students $\% 20$ perception $\% 20$ towards $\% 20$ school $\% 20$ students $\% 20$ librarianship $\% 20$ as $\% 20 \mathrm{a} \% 20$ career

Kolawole, A. A. \&Igwe, K. N. (2016). Treatise on library and information science in an African society. Lagos: Waltodanny Visual Concept.

Mullhall, S. (2014). Careers and career development. In B. Harney and K. Monks (eds) Strategic HRM: research and practice in Ireland. Dublin; Orpen Press, pp.211-229.

Nnadozie, C. O., Akanwa, P. C. \&Nnadozie, C. D. (2013). Impact of entrepreneurship education on the career aspirations of Nigerian para-professional librarians in- training. Academic journal of interdisciplinary studies, 2 (5). 149-161.

Onifade, F, Okoro, C.A. \&Boakye, G.O. (2019). Career Progression of Librarians $\quad$ in Nigeria and Ghana Universities. Information Impact: Journal of Information and Knowledge Management Available from: https://www.researchgate.net/publication/330493498_Career_Progression_of_Librarians_in_ Nigeria_and_Ghana_Universities [accessed Oct.29, 2019]. 
Petricca-Harris, A. \&Mckenna, S. (2013) Identity struggle, professional development and career: A career life history of a human resource management professional. Journal of Management Development 32(8), 823-835.

Stauf, S. \& Bread, W. (2016). 5 reasons why being a librarian isn't boring at all. Retrieved from http://money.com/librarian-job-perks.

Tomaszewski, R. \& MacDonald, K.I. (2009). Identifying subject-specific conferences as professional development opportunities for academic librarians, Journal of Academic Librarianship, 35(6), 583590.

Ugah, A. D. (2014). Entrepreneurship and library and information science profession. In Issa, A. O., Uzuegbu, C. P. and Nwosu, M. C. Entrepreneurship studies and practices in library and information science. Umuahia: zeh Communications. Pp. 81-90.

Uhegbu, A. N. (2009). Research and statistical methods in library and information science. Owerri: Barloz Publishers.

Wilson, Kerry M. and Halpin, Eddie (2006). Convergence and professional identity in the academic library. Journal of Librarianship and Information Science. 38(2), 79-91. https://www.researchgate.net/publication/249750477_Convergence_and_professi onal_identity_in_the_academic_library

Yusuf, F. \&Ilo, P. (2012). Career commitment of staff in academic libraries: a comparative study of two private university libraries in Ogun State Nigeria, Nigerian Library Link. 10(1\&2) 35-48. 